\title{
Analisis Potensi Banjir di Kota Denpasar Menggunakan Metode Analytical Hierarchy Process
}

\author{
Junivan $^{1}$, Linawati ${ }^{2}$, I.A.Dwi Giriantari ${ }^{3}$
}

\begin{abstract}
Natural disasters that almost often occur in every rainy season is a flood. The City of Denpasar experienced a fairly rapid development with various functions such as education, trade and tourism city, due to changes in land use and rapid population development could have a negative impact that is the reduction of soil absorption and the increase of flood prone areas which in the end causing grievances from people in the area. Through four parameters namely flood event, rainfall intensity, area height and density of settlement can determine the potential area of flood disaster in Denpasar City area by using AHP method. The calculation weights of the flood parameters can be generated map of potential areas prone to flooding in the City Denpasar. Provided high potential flood areas of $9 \%$, medium level of $28 \%$ and a low level of $63 \%$ of 43 villages in the City of Denpasar. This result can be an input for all stakeholders as policy makers can make decisions in flood disaster management.
\end{abstract}

Intisari-Bencana alam yang hampir sering terjadi pada setiap musim penghujan adalah banjir. Kota Denpasar mengalami perkembangan pembangunan yang cukup pesat dengan berbagai fungsi antara lain kota pendidikan, perdagangan dan pariwisata, karena mengalami perubahan tata guna lahan dan perkembangan penduduk yang pesat dapat menimbulkan dampak negatif yakni berkurangnya daya resap tanah dan meningkatnya kawasan- kawasan rawan banjir yang pada akhirnya menimbulkan keluhan- keluhan dari masyarakat di daerah tersebut. Lewat 4 (empat) parameter yaitu peristiwa banjir pada beberapa waktu yang lalu, intensitas curah hujan, ketinggiaan wilayah dan kepadatan pemukiman dapat menentukan daerah potensi bencana banjir di wilayah Kota Denpasar dengan menggunakan metode AHP. Bobot perhitungan dari parameter banjir tersebut dapat dihasilkan peta daerah potensi rawan banjir di Kota Denpasar. Diperoleh daerah potensi rawan banjir level tinggi sebesar 9\%, level sedang sebesar $28 \%$ dan level rendah sebesar $63 \%$ dari 43 desa di Kota Denpasar. Hasil ini dapat dijadikan masukan bagi seluruh pemangku kepentingan selaku pengambil kebijakan dapat mengambil keputusan dalam manajemen bencana banjir.

Kata Kunci- AHP, DSS, Banjir, Sistem Informas Geografis, Mapinfo

\section{PENDAHULUAN}

Permasalahan banjir di Kota Denpasar selain disebabkan oleh curah hujan yang tinggi juga disebabkan beberapa faktor lainnya seperti kemiringan lahan, ketinggiaan wilayah (dpl), alih fungsi lahan, sistem drainase yang kurang baik dan sampah masyarakat.

\footnotetext{
${ }^{1}$ UPT.Pusdalops PB BPBD Provinsi Bali, (telp.0361-251177; e-mail: simple.ivan05@gmail.com)

${ }^{2,3}$ Pengajar, Magister Teknik ElektroUniversitas Udayana, Kampus Sudirman Denpasar Bali (telp.0361-239599; fax: 0361239599; e-mail: Linawati@unud.ac.id, dayu.giriantari@yahoo.com)
}

Pada tahun 2012 tercatat Kota Denpasar mengalami kejadian banjir sebanyak 7 kali kejadian (16\%) menempati peringkat ke - 3 di Provinsi Bali, peringkat pertama di Kabupaten Buleleng sebanyak 15 kali kejadian (34\%) dan peringkat kedua di Kabupaten Badung sebanyak 11 kali kejadian (25\%) (Ringkasan Data Kejadian Bencana di Provinsi Bali tahun 2012 UPT Pusdalops PB BPBD Prov. Bali). Lewat peristiwa banjir pada beberapa waktu yang lalu, dibutuhkan suatu pemahaman yang dapat dijadikan masukan bagi seluruh pemangku kepentingan selaku pengambil kebijakan dapat mengambil keputusan dalam manajemen bencana banjir di Kota Denpasar oleh karena itu diperlukan suatu perhitungan potensi banjir yang secara signifika nmeningkatkan kemampuan manajemen resiko bencana banjir[1] untuk lebih memberikan perhatian khusus wilayah mana saja yang mengalami kerentanan terhadap bahaya banjir[2].

Dalam Peraturan Kepala Badan Nasional Penanggulangan Bencana Nomor 02 Tahun 2012 Tentang Pedoman Umum Pengkajian Risiko Bencana metode Analytic Hierarchy Process (AHP) dapat digunakan untuk Pembobotan Faktor kejadian bencana contohnya potensi banjir [3]. Metode ini telah dikembangkan oleh Thomas L. Saaty pada tahun 1970 yang dimaksudkan sebagai alat dalam pengambilan keputusan. [4].

Penelitian mengenai banjir telah banyak diterapkan. diantaranya penelitian[5] yang menggunakan metode AHP yang dikombinasikan dengan Sistem Informasi Geografis (GIS) untuk analisis risiko banjir dan evaluasi di kota Enrile Filipina Utara, selain itu penelitian[6] juga menggunakan metode AHP untuk peramalan banjir di Perlis Thailand dengan parameter curah hujan. Penelitian lainnya[7] memetakan daerah banjir dengan metode skoring dan pembobotan di Kabupaten Jepara dengan parameter curah hujan, ketinggian tanah dan sungai. Pada penelitian ini dibangun juga sistem pendukung keputusan dengan metode AHP menggunakan Sistem Informasi Geografis (SIG) dalam menampilkan peta potensi banjir di Kota Denpasar, kemudian data potensi dibandingkan dengan data kejadian bencana tahun 2011 sampai dengan 2015 sehingga mendapatkan persentase keakuratan potensi banjir.

\section{Metode Penelitian}

\section{A. Gambaran Umum Sistem}

Gambaran umum sistem penelitian ini dibagi menjadi 2 (dua) tahapan yaitu pengumpulan data penyebab bencana banjir kemudian dilakukan analisis perhitungan daerah potensi banjir di Kota Denpasar menggunakan metode Analytical Hierarchy Process (AHP). Secara keseluruhan proses p-ISSN:1693 - 2951; e-ISSN: 2503-2372

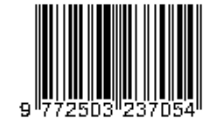


perancangan sistem pendukung keputusan dalam manajemen bencana banjir di Kota Denpasar dapat dilihat pada Gambar 1 berikut ini :

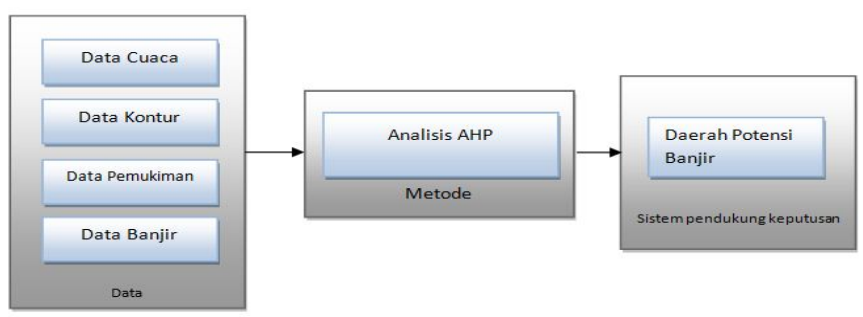

Gambar 1.Gambaran Umum Sistem

\section{B. Alur Penelitian}

Dalam hal ini desain sistem pendukung keputusan digunakan dalam bidang kebencanaan khususnya bencana banjir alur penelitian ini dimulai dengan mengumpulkan data parameter petensi banjir yaitu : cuaca, kontur, kepadatan penduduk dan kejadian banjir. Setelah data terkumpul akan dilakuakan pembobotan dengan menggunakan metode AHP sehingga menghasilkan potensi rawan banjir di Kota Denpasar. Berikut penjelasan dari masing-masing tahapan pada alur penelitian adalah sebagai berikut:

1. Analisis Kebutuhan Sistem

Pada tahap ini dilakukan analisis terhadap kebutuhan sistem didalam merancang sistem perhitungan potensi rawan banjir di kota denpasar dengan menghitung data kejadian bencana[8], data daerah rawan banjir dan data cuaca menggunakan metode AHP.

2. Pengumpulan Data

Adapun sumber data[9] yang digunakan dalam penelitian didapat dari beberapa instansi pemerintah yaitu : UPT Pusdalops PB BPBD Provinsi Bali, BPS Prov. Bali, BPBD Kota Denpasar, Badan Informasi dan Geospasial dan BMKG Wilayah Bali.

3. Penentuan Potensi Daerah Banjir

Parameter yang menentukan wilayah banjir akan di dilakukan perhitungan AHP kemudian akan diberikan skoring dan di overlay menjadi peta potensi banjir. Berikut diagram alur penentuan potensi banjir dapat dilihat pada Gambar 2 .

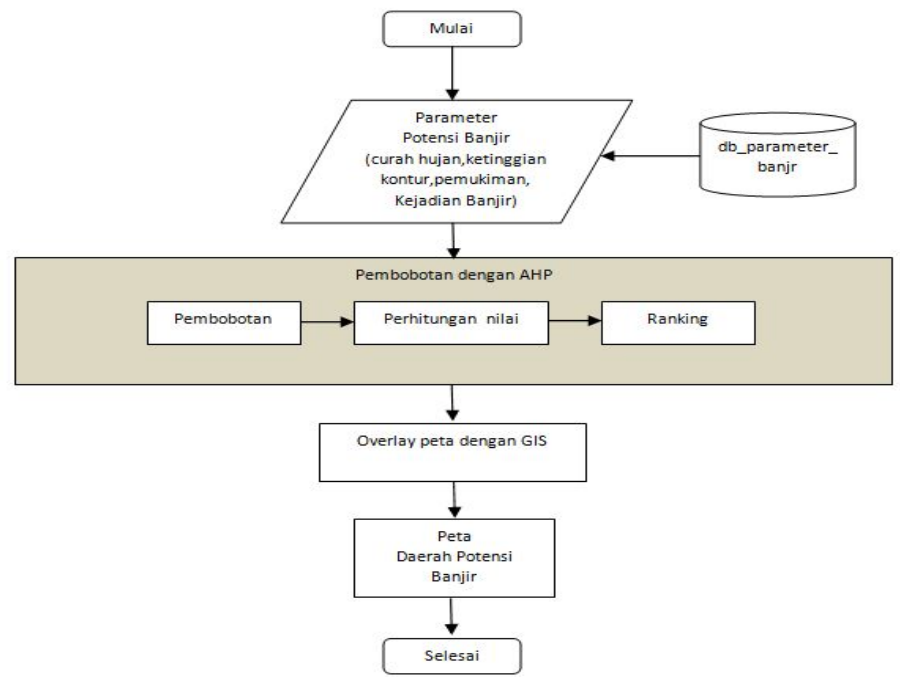

Gambar 2.Alur Proses Penentuan Potensi Banjir

\section{Parameter Potensi Banjir}

Pemberian skor pada masing-masing parameter berbeda sesuai dengan seberapa besar parameter tersebut berpengaruh dalam terjadinya banjir. Berikut beberapa parameter yang akan digunakan dalam menentukan tingkat kerawanan banjir adalah sebagai berikut[10]:

\section{Parameter Prakiraan Cuaca}

Salah satu faktor alam yang berpengaruh besar terhadap terjadinya bencana banjir, adalah intensitas curah hujan. Tingginya curah hujan[11] yang tidak disertai daya dukung lingkungan yang memadai dapat mempengaruhi terjadinya banjir[6]. Semakin tinggi curah hujan semakin besar potensi banjir yang dapat ditimbulkan dalam suatu wilayah. Berikut parameter curah hujan berdasarkan data dari BMKG Bali dapat dilihat pada Tabel 1.

TABEL I.

PARAMETER INTENSITAS CURAH HUJAN

\begin{tabular}{|l|l|l|c|}
\hline No & \multicolumn{1}{|c|}{ Curah hujan } & Kriteria & Skor \\
\hline 1 & $\begin{array}{l}\text { curah hujan dengan volume 5-25 mm } \\
\text { per hari. }\end{array}$ & Ringan & 1 \\
\hline 2 & $\begin{array}{l}\text { curah hujan dengan volume } 26-50 \mathrm{~mm} \\
\text { per hari. }\end{array}$ & Sedang & 3 \\
\hline 3 & $\begin{array}{l}\text { curah hujan tinggi yaitu curah hujan } \\
\text { dengan volume diatas 51 mm per hari. }\end{array}$ & Lebat & 5 \\
\hline
\end{tabular}

2. Parameter Ketinggian Kontur

Daerah yang berada di daerah dataran rendah memiliki tingkat rawan banjir lebih besar dari pada daerah yang berada di berada di daerah atas[7]. Dalam pemberian skoring dengan parameter ketinggian tanah dibedakan berdasarkan ketinggian tanah diatas permukaan laut (dpl) dan dibagi menjadi 5(lima) kelas bisa dilihat pada Tabel 2 .

TABEL II.

PARAMETER KETINGGAN PERMUKAAN LAUT

\begin{tabular}{|c|c|c|c|}
\hline No & Ketinggian DPL & Kriteria & Skor \\
\hline 1 & $0 \mathrm{~m}-20 \mathrm{~m}$ & Sangat rendah & 5 \\
\hline 2 & $21 \mathrm{~m}-50 \mathrm{~m}$ & Rendah & 4 \\
\hline 3 & $51 \mathrm{~m}-100 \mathrm{~m}$ & Sedang & 3 \\
\hline 4 & $101 \mathrm{~m}-300 \mathrm{~m}$ & Tinggi & 2 \\
\hline 5 & $>300 \mathrm{~m}$ & Sangat tinggi & 1 \\
\hline
\end{tabular}

Skor tertinggi diberikan kepada daerah yang wilayah ketinggiannya dibawah $20 \mathrm{~m}$ dari permukaan air laut, sedangkan nilai skor terendah diberikan kepada daerah yang wilayah ketinggiannya diatas $300 \mathrm{~m}$ dari permukaan laut.

\section{Parameter Kepadatan Pemukiman}

Parameter menggunakan komponen fisik yang dianggap dapat menggambarkan tingkat kerapuhan fisik daerah yang terancam tersebut. Komponen fisik yaitu kepadatan pemukiman, semakin tinggi tingkat kepadatan pemukiman maka semakin rentan terhadap bencana banjir[12], pemberian skor terhadap 5 (lima) tipe kepadatan pemukiman dapat dilihat pada Tabel 3 di bawah ini. 


$$
\text { TABEL III. }
$$

PARAMETER KEPADATAN PEMUKIMAN

\begin{tabular}{|c|c|c|}
\hline No & Kepadatan Pemukiman (Unit/KM2) & Skor \\
\hline 1 & $>8.500$ & 8 \\
\hline 2 & $7.500-8.499$ & 7 \\
\hline 3 & $6.000-7.499$ & 6 \\
\hline 4 & $4.000-5.999$ & 5 \\
\hline 5 & $2.500-3.999$ & 4 \\
\hline 6 & $1.250-2.499$ & 3 \\
\hline 7 & $500-1.249$ & 2 \\
\hline 8 & $<500$ & 1 \\
\hline
\end{tabular}

4. Parameter Kejadian Banjir

Data kejadian bencana[13] banjir di wilayah tertentu dapat diambil dalam kurun waktu 1 sampai 5 tahun. Jadi kondisi kejadian banjir juga merupakan penentu kejadian banjir karena rawan banjir selain dilihat dari faktor fisik, tetapi juga faktor sejarah peristiwa. Berikut parameter kejadian banjir disajikan pada Tabel 4.

TABEL IV.

PARAMETER KEJADIAN BANJIR

\begin{tabular}{|c|l|l|c|}
\hline No & \multicolumn{1}{|c|}{ Kajadian Banjir } & \multicolumn{1}{|c|}{ Kriteria } & Skor \\
\hline 1 & $\begin{array}{l}\text { Setiap tahun terendam banjir lebih dari satu } \\
\text { kali }\end{array}$ & Tinggi & 4 \\
\hline 2 & Terendam banjir hampir setiap tahun & Sedang & 3 \\
\hline 3 & Terendam banjir dalam kurun waktu 5 tahun & Rendah & 2 \\
\hline 4 & Tidak pernah banjir & Tidak Pernah & 1 \\
\hline
\end{tabular}

\section{Struktur Heirarki Kriteria Potensi Banjir}

Penyebaran wilayah rawan banjir diketahui dengan melakukan scoring dan overlay dari setiap parameter. Sehingga dilakukan pengharkatan pada parameter curah hujan, ketinggian kontur, daerah aliran sungai, kepadatan pemukiman dan sejarah kejadian banjir.Kriteria yang dibuat merupakan rincian dari permasalahan penentuan selain curah hujan daerah rawan banjir juga ditentukan oleh beberapa kriteria lainnya, berikut hierarki kriteria dapat dilihat pada gambar 3.

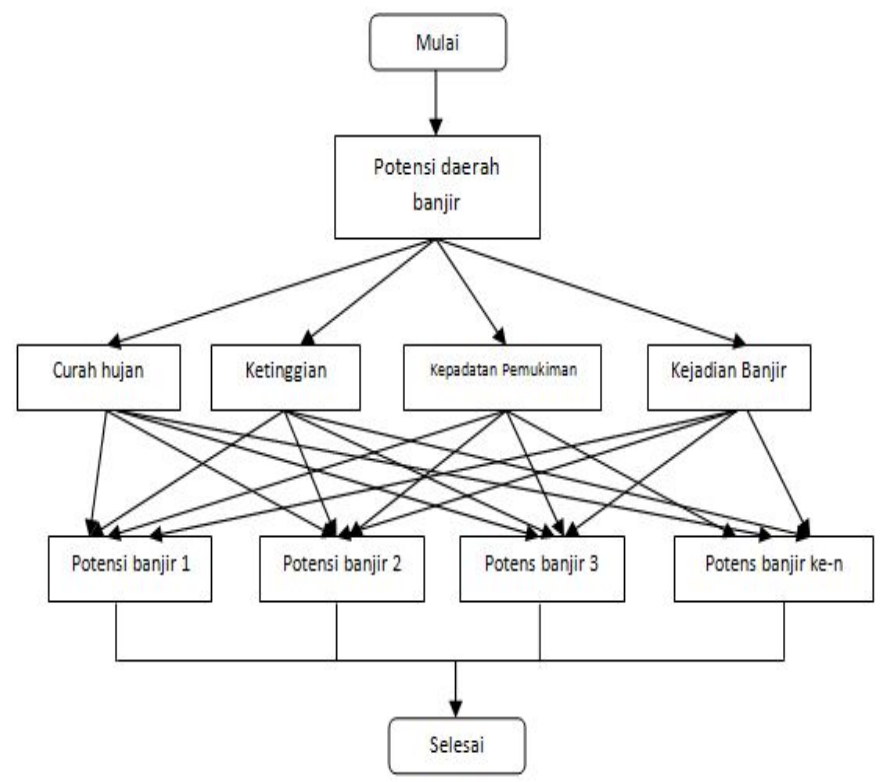

Gambar 3.Hierarki AHP Potensi Daerah Banjir

\section{E. Tahapan metode AHP}

Tahapan - tahapan pengambilan keputusan dalam metode AHP pada dasarnya adalah sebagai berikut[4][14]:

a. Mendefinisikan masalah dan menentukan solusi yang diinginkan.

b. Membuat struktur hirarki yang diawali dengan tujuan umum, dilanjutkan dengan kriteria-kriteria dan alternaif-alternatif pilihan yang ingin dirangking.

c. Membentuk matriks perbandingan berpasangan yang menggambarkan kontribusi relatif atau pengaruh setiap elemen terhadap masing-masing tujuan atau kriteria yang setingkat diatasnya. Perbandingan dilakukan berdasarkan pilihan atau judgement dari pembuat keputusan dengan menilai tingkat tingkat kepentingan suatu elemen dibandingkan elemen lainnya. Untuk mengisi nilai pada matrik menggunakan aksioma reciprocal. Jika aij adalah elemen baris ke i dan elemen kolom ke j maka matrik segitiga diisi dengan rumus :

$a_{j i}=\frac{1}{a_{i j}}$

Keterangan :

$a_{j i}=$ elemen pada kolom baris

$a_{i j}=$ elemen pada baris kolom

dan semua nilai elemen matrik adalah positif, atau $a_{i j}>0$.

d. Menormalkan data dengan membagi nilai dari setiap elemen di dalam matriks yang berpasangan dengan nilai total dari setiap kolom.

e. Menghitung nilai eigen vector dan menguji konsistensinya, jika tidak konsisten maka pengambilan data (preferensi) perlu diulangi. Nilai eigen vector yang dimaksud adalah nilai eigen vector maximum.

f. Mengulangi langkah 3, 4, dan 5 untuk seluruh tingkat hirarki.

g. Menghitung eigen vector dari setiap matriks perbandingan berpasangan. Nilai eigen vector merupakan bobot setiap elemen. Langkah ini untuk mensintesis pilihan dalam penentuan prioritas elemen-elemen pada tingkat hirarki terendah sampai pencapaian tujuan.

h. Menguji konsistensi hirarki. Jika tidak memenuhi dengan $\mathrm{CR}<0,100$ maka penilaian harus diulang kembali. Untuk menguji konsistensi dengan menggunakan rumus :

$C I=\frac{(\lambda m a k s-1)}{n-1}$

Keterangan :

$C I=$ Rasio penyimpangan

$\lambda$ maks $=$ eigenvalue maksimum

$\mathrm{n}=$ ukuran matriks 
Apabila CI bernilai nol, berarti matriks konsisten, batas ketidakkonsistensi(inconsistency) yang ditetapkan Saaty diukur dengan menggunakan Rasio Konsistensi $(C R)$, yakni perbandingan indeks konsistensi dengan nilai random indeks $(R I)$. Nilai ini bergantung pada ordo matriks $n$. Dengan demikian, Rasio Konsistensi dapat dirumuskan :

$$
C R=\frac{C I}{R I}
$$

Dimana RI (Random Index) bergantung pada jumlah kriteria seperti pada tabel 5.

TABEL V.

NILAI RANDOM INDEX

\begin{tabular}{l|l|l|r|r|r|r|r|r|r|r|}
\hline $\mathbf{n}$ & 1 & 2 & 3 & 4 & 5 & 6 & 7 & 8 & 9 & 10 \\
\hline $\mathbf{R I}$ & 0 & 0 & 0.58 & 0.9 & 1.12 & 1.24 & 1.32 & 1.41 & 1.45 & 1.49 \\
\hline
\end{tabular}

\section{PENGEMBANGAN APLIKASI}

Berikut ini adalah hasil pengembangan aplikasi yang dilakukan pada penelitan ini.

\section{A. Antar Muka Sistem}

Sistem ini menggunakan bahasa visual basic dengan database mysql dan untuk Sistem Informasi Geografis menggunakan MapInfo 11.5. Sistem Informasi Geografis (SIG) ini merupakan sistem yang berbasiskan komputer yang digunakan untuk menyimpan dan memanipulasi informasi-informasi geografi. SIG ini dirancang untuk mengumpulkan, menyimpan, dan menganalisis objek-objek dan fenomena dimana lokasi merupakan karakteristik yang penting untuk dianalisis[15][16][17]. Antar Muka Sistem merupakan tampilan pertama kali sistem pada saat dijalankan.berikut gambar 4 merupakan desain tampilan interface halaman awal sistem.

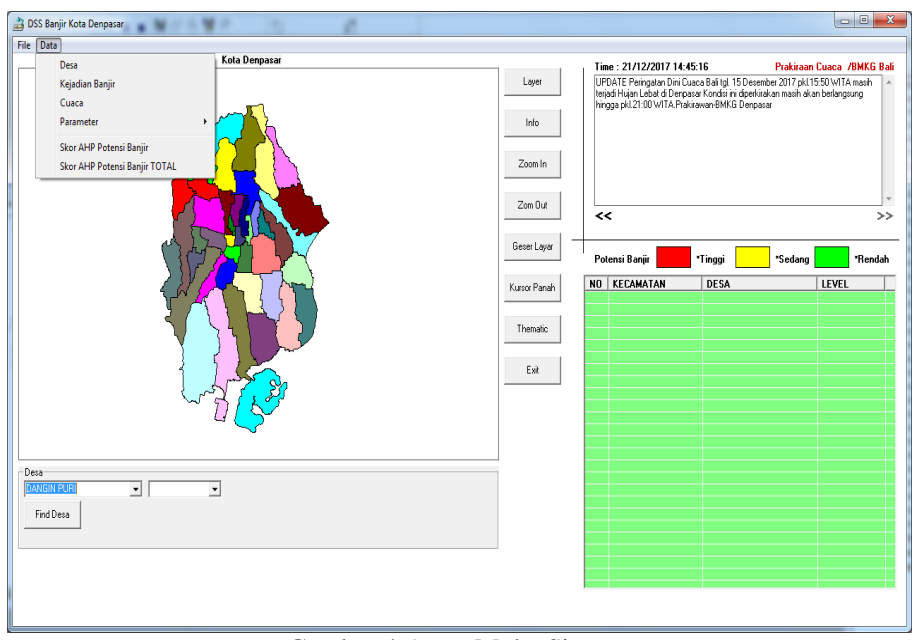

Gambar 4.Antar Muka Sistem

Ada beberapa menu yang dimiki oleh sistem pendukung keputusan banjir ini yaitu :
1. User
2. Data Desa
3. Kejadian Banjir
4. Cuaca
5. Parameter Banjir

\section{Skor AHP Pontensi Banjir}

\section{B. Pengumpulan Data}

Ada beberapa data yang diinput ke dalam sistem yaitu data desa di kota Denpasar sebanyak 43 desa dengan data ketinggian kontur dan jumlah penduduk sumber data dari Badan Pusat Statistik (BPS) Bali Tahun 2015 dapat dilihat pada gambar 5 untuk desain input interface desa.

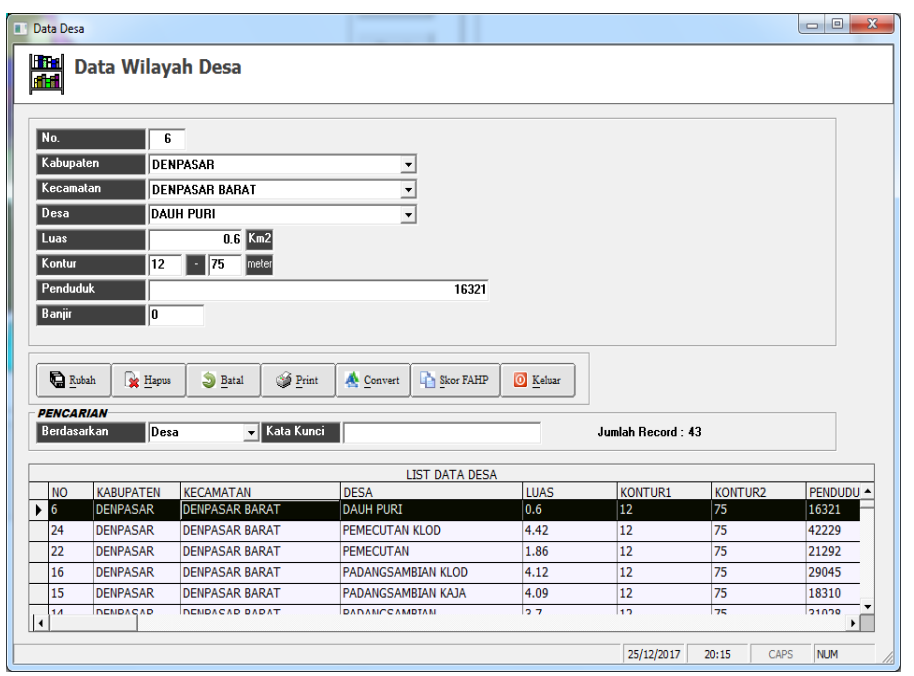

Gambar 5.Form Input Desa

Untuk Kejadian Banjir dari Tahun 2011 sampai dengan 2015 sumber data dari UPT Pusdalops PB BPBD Prov Bali, bisa dilihat pada gambar 6 untuk desain input interfacenya.

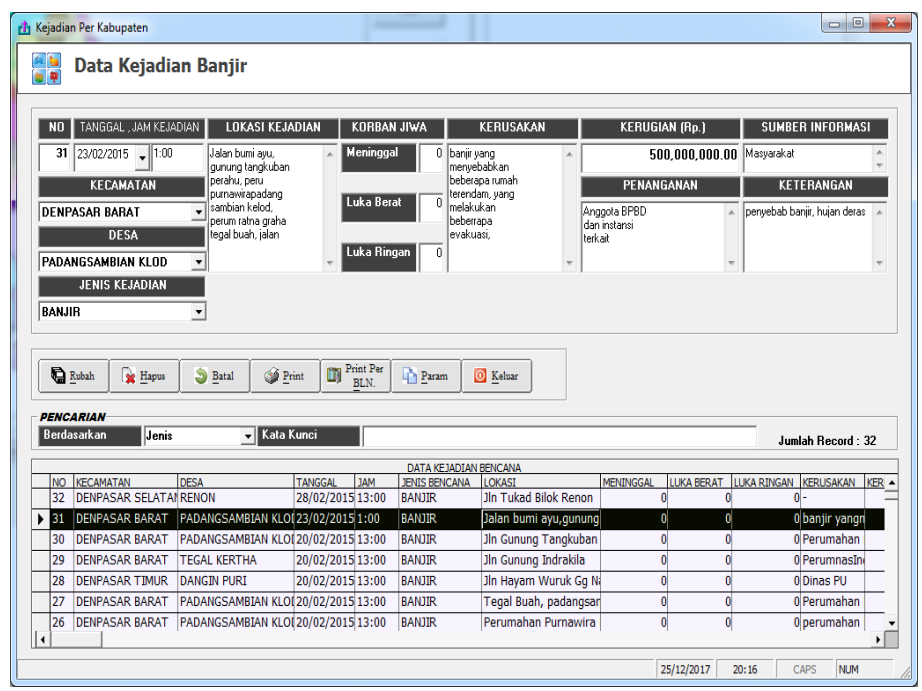

Gambar 6 Form Input Kejadian Banjir

\section{Interface Perhitungan Matrik Perbandingan}

Perhitungan AHP berguna untuk menemukan konsistensi nilai matriks perbandingannya. Untuk input matriks perbandingan antar kriteria parameter potensi banjir dapat dilihat pada gambar 7. 


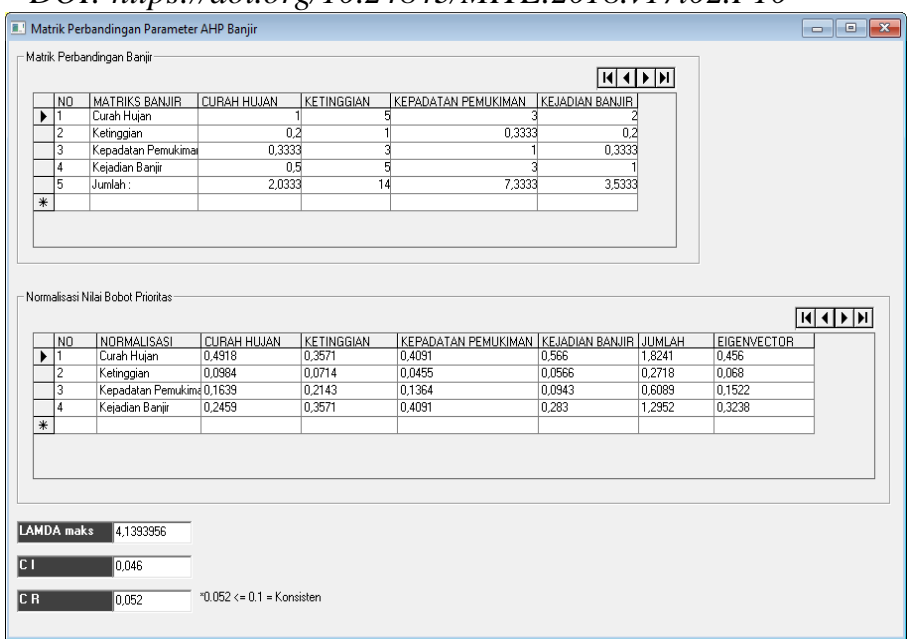

Gambar 7. Form Matrik Perbandingan Parameter AHP Banjir

\section{IV.HASIL DAN PEMBAHASAN}

Tahapan atau langkah-langkah penyelesaian menggunakan metode AHP adalah sebagai berikut :

\section{A. Perhitungan Nilai Bobot Banjir}

Berikut tahapan perhitungan untuk nilai bobot parameter potensi banjir:

1. Penghitungan AHP yang berguna untuk menemukan konsistensi nilai matriks perbandingannya. Input nilai matriks perbandingan antar kriteria dapat dilihat pada tabel 6 .

TABEL VI.

MATRIK PERBANDINGAN

\begin{tabular}{|l|r|r|r|r|}
\hline \multicolumn{1}{|c|}{$\begin{array}{c}\text { Matriks } \\
\text { Banjir }\end{array}$} & \multicolumn{1}{|c|}{$\begin{array}{c}\text { Curah } \\
\text { Hujan }\end{array}$} & Ketinggian & $\begin{array}{c}\text { Kepadatan } \\
\text { Pemukiman }\end{array}$ & $\begin{array}{l}\text { Kejadian } \\
\text { Banjir }\end{array}$ \\
\hline $\begin{array}{l}\text { Curah } \\
\text { Hujan }\end{array}$ & 1 & 5 & 3 & 2 \\
\hline Ketinggian & 0,2 & 1 & 0,333 & 0,2 \\
\hline $\begin{array}{l}\text { Kepadatan } \\
\text { Penduduk }\end{array}$ & 0,333 & 3 & 1 & 0,333 \\
\hline $\begin{array}{l}\text { Kejadian } \\
\text { Banjir }\end{array}$ & 0,5 & 5 & 3 & 1 \\
\hline Jumlah : & 2,033 & 14 & 7,333 & 3,533 \\
\hline
\end{tabular}

2. Nilai inputan perbandingan matriks di atas kemudian diproses untuk mencari bobot vektor prioritas, lamda, CI, dan CR. Sebelum menghitung nilai bobot prioritas, setiap sel pada kolom matriks dibagi dengan jumlah kolom pada tiap selnya, mengacu pada “(1)" untuk kolom pertama :

Curah hujan $=\frac{1}{2,03}=0,4918$

Ketinggian $=\frac{0,2}{2,03}=0,0984$

Kepadatan Pemukiman $=\frac{0,33}{2,03}=0,1639$

Junivan : Analisis Potensi Banjir...
Kejadian Banjir $=\frac{0,5}{2,03}=0,2459$, begitu seterusnya untuk kolom 2, 3 dan 4.

3. Menghitung nilai bobot prioritas yaitu untuk hasil pembagian sel yang telah diperoleh pada setiap baris matriks dijumlahkan, kemudian dibagi dengan banyaknya sel pada baris tersebut (banyak kriteria = 4) dapat dilihat pada tabel 7 .

TABEL VII.

NILAI BOBOT PRIORITAS PARAMETER POTENSI BANJIR

\begin{tabular}{|c|c|c|c|c|c|}
\hline & $\begin{array}{l}\text { Curah } \\
\text { Hujan }\end{array}$ & $\begin{array}{l}\text { Ketin } \\
\text { ggian }\end{array}$ & $\begin{array}{l}\text { Kepadatan } \\
\text { Pemukiman }\end{array}$ & $\begin{array}{l}\text { Kejadian } \\
\text { Banjir }\end{array}$ & $\begin{array}{l}\text { Eigenve } \\
\text { ctor }\end{array}$ \\
\hline $\begin{array}{l}\text { Curah } \\
\text { Hujan }\end{array}$ & 0,492 & 0,357 & 0,409 & 0,566 & 0,4560 \\
\hline & \multicolumn{4}{|c|}{$=\frac{0,492+0,357+0,409+0,566}{4}=0,4560$} & \\
\hline \multirow[t]{2}{*}{ Ketinggian } & 0,098 & 0,071 & 0,045 & 0,057 & 0,0680 \\
\hline & \multicolumn{4}{|c|}{$=\frac{0,098+0,071+0,045+0,057}{4}=0,0680$} & \\
\hline \multirow[t]{2}{*}{$\begin{array}{l}\text { Kepadatan } \\
\text { Penduduk }\end{array}$} & 0,164 & 0,214 & 0,136 & 0,094 & 0,1522 \\
\hline & \multicolumn{4}{|c|}{$=\frac{0,164+0,214+0,136+0,094}{4}=0,1522$} & \\
\hline \multirow[t]{2}{*}{$\begin{array}{l}\text { Kejadian } \\
\text { Banjir }\end{array}$} & 0,246 & 0,357 & 0,409 & 0,283 & 0,3238 \\
\hline & \multicolumn{4}{|c|}{$=\frac{0,357+0,357+0,409+0,283}{4}=0,3238$} & \\
\hline
\end{tabular}

4. Dengan menggunakan rumus AHP Pada Bab II menghitung nilai eigen maksimum $(\lambda$ maks $)$, nilai $\mathrm{CI}$ dan CR :

$\lambda$ maks : $(0,4560 \times 2,033)+(0,0680 \times 14)+(0,1522 \times$ $7,333)+(0,3238 \times 3,533)=4,139$

mengacu pada “(2)”, CI $=(4,139-4) /(4-1)=0,046$ Karena jumlah parameter kriteria ada 4 maka $\mathrm{n}=4 ; \mathrm{RI}=0,9$ yang didapat dari tabel 5 Random Index. Mengacu pada “(3)" $\mathrm{CR}=\frac{C I}{R I}=\frac{0,046}{0.9}=0,052<=0,1=$ konsisten.

\section{B. Perhitungan Nilai Parameter Banjir}

Ada 4(empat) parameter kriteria banjir yaitu, curah hujan, kontur, kepadatan pemukiman dan kejadian banjir yang masing masing dihitung menggunakan langkah - langkah AHP untuk mendapat nilai Eigenvector yang dihitung di dalam sistem aplikasi sebagai berikut :

1. Nilai eigenvector curah hujan bisa dilihat pada tabel 8.

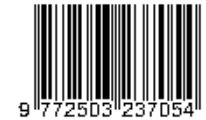


TABEL VIII.

NILAI PARAMETER KRITERIA CURAH HUJAN

\begin{tabular}{|c|c|c|}
\hline NO & HUJAN & EIGENVECTOR \\
\hline 1 & RINGAN & 0,11111 \\
\hline 2 & SEDANG & 0,33333 \\
\hline 3 & LEBAT & 0,55556 \\
\hline
\end{tabular}

Untuk eigenvector parameter hujan skor tertinggi pada hujan dengan intenstas lebat dengan nilai sebesar 0,5556.

2. Untuk perhitungan kontur dapat dapat dilihat pada Tabel 9 dibawah ini.

TABEL IX

NILAI KRITERIA KONTUR WILAYAH

\begin{tabular}{|c|l|r|}
\hline NO & \multicolumn{3}{|c|}{ KECAMATAN } & EIGENVECTOR KONTUR \\
\hline 1 & DENPASAR BARAT & 0,02013 \\
\hline 2 & DENPASAR SELATAN & 0,03356 \\
\hline 3 & DENPASAR TIMUR & 0,02013 \\
\hline 4 & DENPASAR UTARA & 0,02013 \\
\hline
\end{tabular}

Nilai eigenvector tertingi pada wilayah kecamatan Denpasar Selatan dengan nilai sebesar 0,03356. Nilai Kontur ini dapat di kelompokkan menjadi 4 (empat) bagian Kecamatan.

3. Nilai eigenvector Kepadatan Penduduk dapat dilihat pada tabel 10 .

TABEL $X$.

NILAI KRITERIA KEPADATAN PENDUDUK

\begin{tabular}{|c|c|c|c|}
\hline NO & KECAMATAN & DESA & EIGENVECTOR \\
\hline 1 & DENPASAR BARAT & DAUH PURI & 0,02888 \\
\hline 2 & DENPASAR BARAT & PEMECUTAN KLOD & 0,02888 \\
\hline 3 & DENPASAR BARAT & PEMECUTAN & 0,02888 \\
\hline 4 & DENPASAR BARAT & PADANGSAMBIAN KLOD & 0,02166 \\
\hline 5 & DENPASAR BARAT & PADANGSAMBIAN KAJA & 0,01805 \\
\hline 6 & DENPASAR BARAT & PADANGSAMBIAN & 0,02527 \\
\hline 7 & DENPASAR BARAT & DAUH PURI KLOD & 0,02888 \\
\hline 8 & DENPASAR BARAT & DAUH PURI KAUH & 0,02888 \\
\hline 9 & DENPASAR BARAT & DAUH PURI KANGIN & 0,02888 \\
\hline 10 & DENPASAR BARAT & TEGAL KERTHA & 0,02888 \\
\hline 11 & DENPASAR BARAT & TEGAL HARUM & 0,02888 \\
\hline 12 & DENPASAR SELATAN & PEMOGAN & 0,01805 \\
\hline 13 & DENPASAR SELATAN & RENON & 0,02527 \\
\hline 14 & DENPASAR SELATAN & SANUR & 0,01805 \\
\hline 15 & DENPASAR SELATAN & SANUR KAJA & 0,01805 \\
\hline 16 & DENPASAR SELATAN & SANUR KAUH & 0,01444 \\
\hline 17 & DENPASAR SELATAN & SERANGAN & 0,01083 \\
\hline 18 & DENPASAR SELATAN & PEDUNGAN & 0,01805 \\
\hline 19 & DENPASAR SELATAN & PANJER & 0,02888 \\
\hline 20 & DENPASAR SELATAN & SESETAN & 0,02166 \\
\hline 21 & DENPASAR SELATAN & SIDAKARYA & 0,02166 \\
\hline 22 & DENPASAR TIMUR & SUMERTA KELOD & 0,02527 \\
\hline 23 & DENPASAR TIMUR & SUMERTA KAUH & 0,02888 \\
\hline 24 & DENPASAR TIMUR & SUMERTA & 0,02888 \\
\hline 25 & DENPASAR TIMUR & SUMERTA KAJA & 0,02888 \\
\hline 26 & DENPASAR TIMUR & PENATIH DANGIN PURI & 0,01444 \\
\hline 27 & DENPASAR TIMUR & PENATIH & 0,01805 \\
\hline 28 & DENPASAR TIMUR & DANGIN PURI KLOD & 0,01805 \\
\hline 29 & DENPASAR TIMUR & KESIMAN & 0,02166 \\
\hline 30 & DENPASAR TIMUR & KESIMAN KERTALANGU & 0,01805 \\
\hline 31 & DENPASAR TIMUR & KESIMAN PETILAN & 0,01805 \\
\hline 32 & DENPASAR TIMUR & DANGIN PURI & 0,02888 \\
\hline 33 & DENPASAR UTARA & PEGUYANGAN & 0,01444 \\
\hline 34 & DENPASAR UTARA & UBUNG & 0,02888 \\
\hline 35 & DENPASAR UTARA & TONJA & 0,02888 \\
\hline 36 & DENPASAR UTARA & DANGIN PURI KAJA & 0,02888 \\
\hline 37 & DENPASAR UTARA & DANGIN PURI KANGIN & 0,02888 \\
\hline 38 & DENPASAR UTARA & DANGIN PURI KAUH & 0,02888 \\
\hline 39 & DENPASAR UTARA & PEMECUTAN KAJA & 0,02527 \\
\hline 40 & DENPASAR UTARA & DAUH PURI KAJA & 0,02888 \\
\hline 41 & DENPASAR UTARA & PEGUYANGAN KANGIN & 0,01444 \\
\hline 42 & DENPASAR UTARA & PEGUYANGAN KAJA & 0,01083 \\
\hline 43 & DENPASAR UTARA & UBUNG KAJA & 0,02166 \\
\hline
\end{tabular}

Eigenvector penduduk paling besar pada desa Tegal Kerta dengan nilai sebesar 0,02888 dengan kepadatan pemukiman sebesar 60.751 jiwa per kilometer persegi.Sedangkan skor penduduk terkecil pada desa Peguyangan Kaja dengan nilai sebesar 0,01083 .

4. Nilai eigenvector Kejadian Banjir dari tahun 2011 sampai dengan tahun 2015 dapat dilihat pada tabel 11.

TABEL XI.

\section{NILAI KRITERIA KEJADIAN BANJIR}

\begin{tabular}{|c|c|c|c|c|c|c|c|}
\hline NO & KECAMATAN & DESA & 2011 & 2012 & 2013 & 2014 & 2015 \\
\hline 1 & DENPASAR BARAT & DAUH PURI & 0,01613 & 0,02128 & 0,01887 & 0,01961 & 0,01724 \\
\hline 2 & DENPASAR BARAT & PEMECUTAN KLOD & 0,06452 & 0,06383 & 0,0566 & 0,01961 & 0,01724 \\
\hline 3 & DENPASAR BARAT & PEMECUTAN & 0,01613 & 0,02128 & 0,01887 & 0,01961 & 0,01724 \\
\hline 4 & DENPASAR BARAT & PADANGSAMBIAN KLOD & 0,01613 & 0,06383 & 0,0566 & 0,05882 & 0,06897 \\
\hline 5 & DENPASAR BARAT & PADANGSAMBIAN KAJA & 0,04839 & 0,02128 & 0,01887 & 0,01961 & 0,05172 \\
\hline 6 & DENPASAR BARAT & PADANGSAMBIAN & 0,01613 & 0,02128 & 0,0566 & 0,05882 & 0,05172 \\
\hline 7 & DENPASAR BARAT & DAUH PURI KLOD & 0,01613 & 0,02128 & 0,01887 & 0,01961 & 0,01724 \\
\hline 8 & DENPASAR BARAT & DAUH PURI KAUH & 0,01613 & 0,02128 & 0,01887 & 0,01961 & 0,01724 \\
\hline 9 & DENPASAR BARAT & DAUH PURI KANGIN & 0,01613 & 0,02128 & 0,01887 & 0,01961 & 0,01724 \\
\hline 10 & DENPASAR BARAT & TEGAL KERTHA & 0,01613 & 0,02128 & 0,01887 & 0,01961 & 0,05172 \\
\hline 11 & DENPASAR BARAT & TEGAL HARUM & 0,01613 & 0,02128 & 0,01887 & 0,01961 & 0,01724 \\
\hline 12 & DENPASAR SELATAN & PEMOGAN & 0,01613 & 0,02128 & 0,01887 & 0,01961 & 0,01724 \\
\hline 13 & DENPASAR SELATAN & RENON & 0,01613 & 0,02128 & 0,01887 & 0,01961 & 0,05172 \\
\hline 14 & DENPASAR SELATAN & SANUR & 0,01613 & 0,02128 & 0,01887 & 0,05882 & 0,05172 \\
\hline 15 & DENPASAR SELATAN & SANUR KAJA & 0,01613 & 0,02128 & 0,01887 & 0,01961 & 0,01724 \\
\hline 16 & DENPASAR SELATAN & SANUR KAUH & 0,01613 & 0,02128 & 0,01887 & 0,01961 & 0,01724 \\
\hline 17 & DENPASAR SELATAN & SERANGAN & 0,01613 & 0,02128 & 0,01887 & 0,01961 & 0,01724 \\
\hline 18 & DENPASAR SELATAN & PEDUNGAN & 0,01613 & 0,02128 & 0,01887 & 0,01961 & 0,01724 \\
\hline 19 & DENPASAR SELATAN & PANJER & 0,01613 & 0,02128 & 0,0566 & 0,01961 & 0,01724 \\
\hline 20 & DENPASAR SELATAN & SESETAN & 0,01613 & 0,02128 & 0,01887 & 0,01961 & 0,01724 \\
\hline 21 & DENPASAR SELATAN & SIDAKARYA & 0,01613 & 0,02128 & 0,01887 & 0,01961 & 0,01724 \\
\hline 22 & DENPASAR TIMUR & SUMERTA KELOD & 0,01613 & 0,02128 & 0,01887 & 0,01961 & 0,01724 \\
\hline 23 & DENPASAR TIMUR & SUMERTA KAUH & 0,01613 & 0,02128 & 0,01887 & 0,01961 & 0,01724 \\
\hline 24 & DENPASAR TIMUR & SUMERTA & 0,01613 & 0,02128 & 0,01887 & 0,01961 & 0,01724 \\
\hline 25 & DENPASAR TIMUR & SUMERTA KAJA & 0,01613 & 0,02128 & 0,01887 & 0,01961 & 0,01724 \\
\hline 26 & DENPASAR TIMUR & PENATIH DANGIN PURI & 0,04839 & 0,02128 & 0,01887 & 0,01961 & 0,01724 \\
\hline 27 & DENPASAR TIMUR & PENATIH & 0,01613 & 0,02128 & 0,0566 & 0,01961 & 0,01724 \\
\hline 28 & DENPASAR TIMUR & DANGIN PURI KLOD & 0,01613 & 0,02128 & 0,01887 & 0,01961 & 0,01724 \\
\hline 29 & DENPASAR TIMUR & KESIMAN & 0,01613 & 0,02128 & 0,01887 & 0,01961 & 0,01724 \\
\hline 30 & DENPASAR TIMUR & KESIMAN KERTALANGU & 0,01613 & 0,02128 & 0,01887 & 0,01961 & 0,01724 \\
\hline 31 & DENPASAR TIMUR & KESIMAN PETILAN & 0,01613 & 0,02128 & 0,01887 & 0,01961 & 0,01724 \\
\hline 32 & DENPASAR TIMUR & DANGIN PURI & 0,01613 & 0,02128 & 0,01887 & 0,01961 & 0,05172 \\
\hline 33 & DENPASAR UTARA & PEGUYANGAN & 0,04839 & 0,02128 & 0,01887 & 0,05882 & 0,01724 \\
\hline 34 & DENPASAR UTARA & UBUNG & 0,01613 & 0,02128 & 0,01887 & 0,01961 & 0,01724 \\
\hline 35 & DENPASAR UTARA & TONJA & 0,04839 & 0,02128 & 0,01887 & 0,01961 & 0,01724 \\
\hline 36 & DENPASAR UTARA & DANGIN PURI KAJA & 0,01613 & 0,02128 & 0,01887 & 0,01961 & 0,01724 \\
\hline 37 & DENPASAR UTARA & DANGIN PURI KANGIN & 0,01613 & 0,02128 & 0,01887 & 0,01961 & 0,01724 \\
\hline 38 & DENPASAR UTARA & DANGIN PURI KAUH & 0,01613 & 0,02128 & 0,01887 & 0,01961 & 0,01724 \\
\hline 39 & DENPASAR UTARA & PEMECUTAN KAJA & 0,01613 & 0,02128 & 0,01887 & 0,01961 & 0,01724 \\
\hline 40 & DENPASAR UTARA & DAUH PURI KAJA & 0,01613 & 0,02128 & 0,01887 & 0,01961 & 0,01724 \\
\hline 41 & DENPASAR UTARA & PEGUYANGAN KANGIN & 0,06452 & 0,02128 & 0,01887 & 0,01961 & 0,01724 \\
\hline 42 & DENPASAR UTARA & PEGUYANGAN KAJA & 0,06452 & 0,02128 & 0,01887 & 0,01961 & 0,01724 \\
\hline 43 & DENPASAR UTARA & UBUNG KAJA & 0,04839 & 0,02128 & 0,01887 & 0,01961 & 0,01724 \\
\hline
\end{tabular}

Nilai potensi banjir berdasarkan eigenvector tertinggi untuk tahun 2011 pada Desa Pemecutan Klod, Peguyangan Kangin dan Peguyangan Kaja dengan nilai 0,06452. Tahun 2012 nilai tertinggi 0,06383 pada Desa Padangsambian Klod, tahun 2013 nilai tertinggi 0,0566 pada Desa Padangsambian Klod, tahun 2014 nilai tertinggi 0,05882 Pada Desa Padangsambian Klod dan tahun 2015 nilai tertinggi 0,06897 juga pada desa Padangsambian Klod. Selanjutnya nilai ini dibandingkan dari tahun 2011 sampai dengan tahun 2015 yang dapat dilihat pada point $\mathrm{C}$ dibawah ini.

\section{Perbandingan Nilai Potensi Banjir}


Dengan melakukan perhitungan AHP terhadap potensi banjir di Kota Denpasar maka didapat nilai potensi banjir berdasarkan eigenvector dengan nilai parameter curah hujan tinggi masing masing dari tahun 2011 sampai dengan tahun 2015 sebagai berikut :

\section{Denpasar Barat}

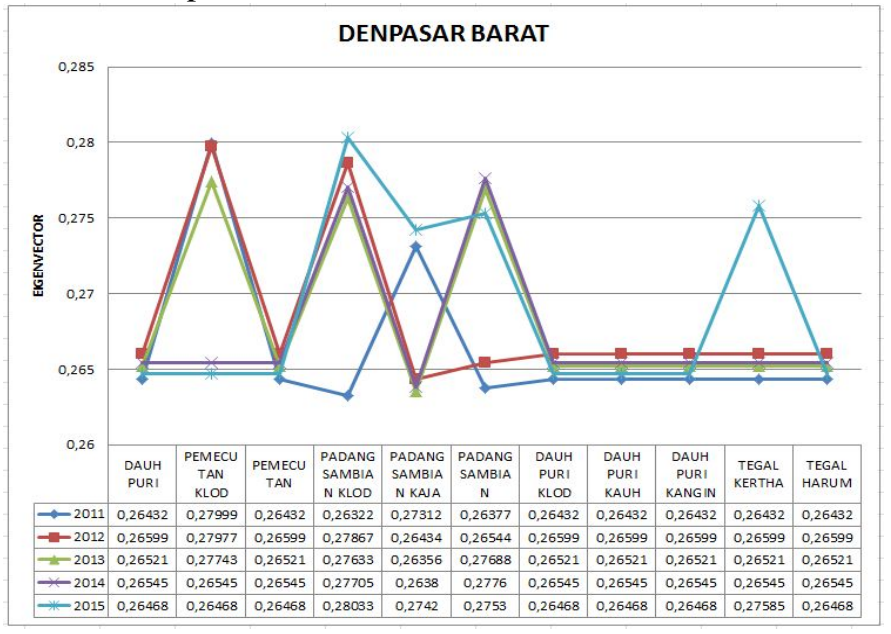

Gambar 8. Perbandingan Nilai Potensi Banjir Denpasar Barat

Kecamatan Denpasar Barat memiliki 11 wilayah desa, yang mendapatkan nilai potensi banjir teringgi pada tahun 2015 adalah Padang Sambian Klod dengan nilai 0,2803 dengan kejadian banjir sebanyak 4 kali. Padang Sambian Klod nilai potensi banjir tiap tahun naik karena hampir tiap tahun terjadi banjir, total banjir sampai 7 kali kejadian. Untuk Pemecutan Klod Tahun 2011 mendapatkann nilai potensi banjir sebesar 0,2799 dengan kejadian banjir sebanyak 2 kali kejadian.

\section{Denpasar Selatan}

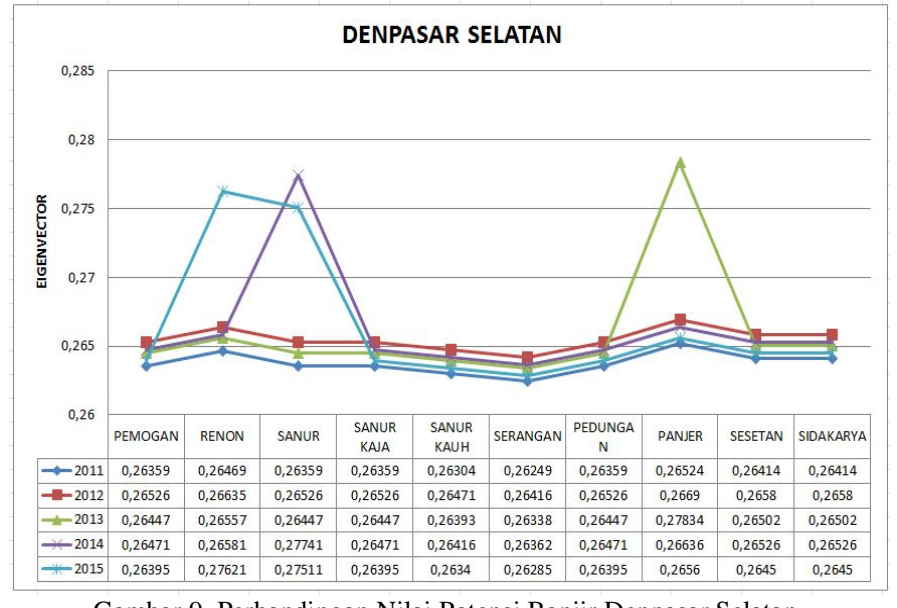

Gambar 9. Perbandingan Nilai Potensi Banjir Denpasar Selatan

Untuk Kecamatan Denpasar Selatan memilik 10 wilayah desa, dari tahun 2011 sampai dengan tahun 2015 nilai potensi banjir tertinggi yaitu pada desa Panjer dengan nilai sebesar 0.,7834 dengan kejadian banjir sebanyak 1 kali kejadian. Untuk wilayah Sanur pada tahun 2014 dan tahun 2015 nilai potensi banjir menjadi masing - masing sebesar 0.27741 dan 0.27511 , hal ini karena terjadi banjir 1 kali dari tahun 2014 sampai dengan tahun 2015. Total kejadian banjir di daerah Denpasar Selatan dari tahun 2011 sampai dengan 2015 sebanyak 4 kali kejadian.

3. Denpasar Timur

Junivan : Analisis Potensi Banjir...

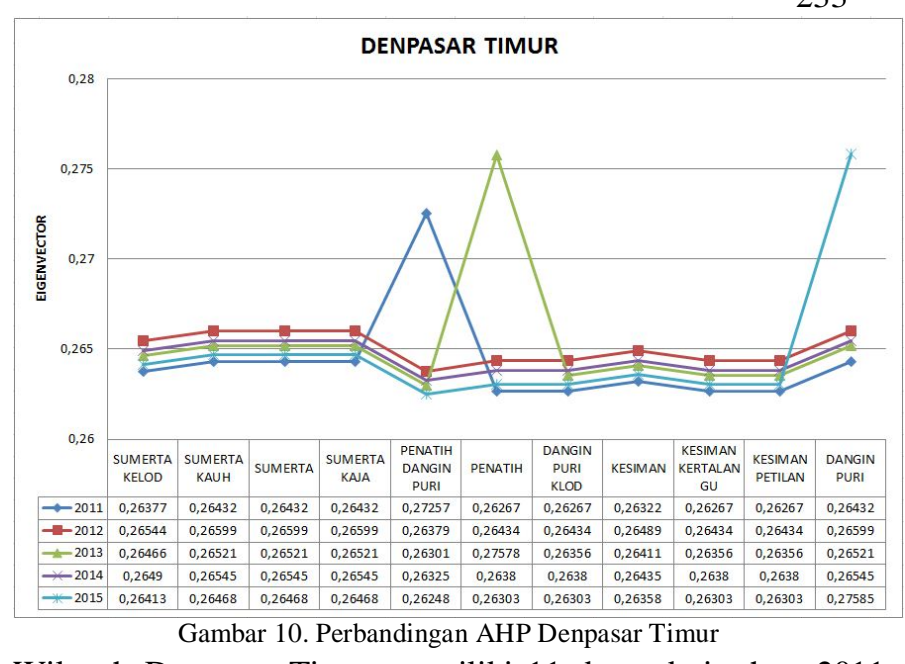

Wilayah Denpasar Timur memiliki 11 desa, dari tahun 2011 sampai dengan tahun 2015 kecenderungan terjadi banjir di sangat sedikit hanya 3 kali kejadian banjir. Wilayah yang terjadi banjir hanya di desa Penatih Dangin Puri dengan potensi banjir sebesar 0,27257 pada tahun 2011 terjadi banjir sebanyak 1 kali kejadian. Untuk desa Penatih mendapatkan potensi sebesar 0,27578 pada tahun 2013 terjadi banjir sebanyak 1 kali.Pada tahun 2015 terjadi banjir 1 kali di desa Dangin Puri dengan nilai potensi sebesar 0,27585.

\section{Denpasar Utara}

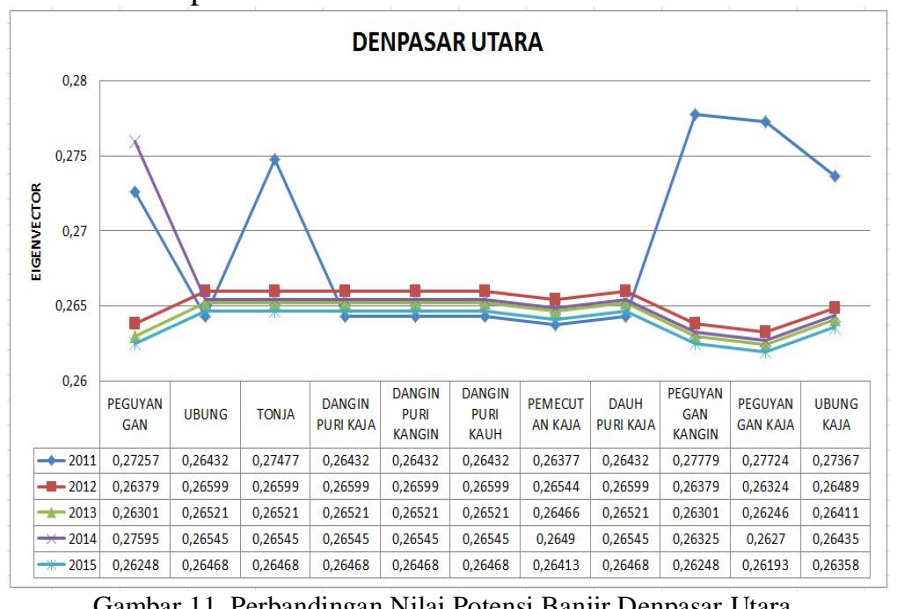

Gambar 11. Perbandingan Nilai Potensi Banjir Denpasar Utara

Wilayah Denpasar Utara memiliki 11 desa, dari tahun 2011 sampai dengan tahun 2015 terjadi banjir sebanyak 8 kali kejadian. Desa Peguyangan terjadi banjir 2 kali di tahun 2011 dan 2014 denga masing masing nilai potensi banjir sebesar 0,27257 dan 0,27595. Desa Tonja nilai potensi sebesar 0,27477 dengan 1 kali kejadian banjir pada tahun 2011, pada desa Peguyangan Kangin dengan nilai potensi sebesar 0,27779 dengan kejadian banjir sebanyak 2 kali kejadian, desa Peguyangan Kaja juga terjadi kejadian banjir sebanyak 2 kali kejadian dengan nilai potensi sebesar 0,27724 dan desa Ubung Kaja terjadi banjir 1 kali dengan nilai eigenvector sebesar $0,27367$.

D. Nilai Potensi Banjir Total dan Overlay Menggunakan MapInfo

Perhitungan AHP terhadap potensi banjir di Kota Denpasar didapat dari nilai eigenvector curah hujan intensitas

p-ISSN:1693 - 2951; e-ISSN: 2503-2372

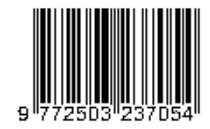


tinggi, eigenvector kontur, eigenvector kepadatan penduduk dan eigenvector kejadian banjir total keseluruhan dari tahun 2011 sampai dengan 2015 dihitung menggunakan sistem mengacu pada "(1)”,“(2)”,"(3)” dapat dilihat pada gambar 12 dibawah ini.

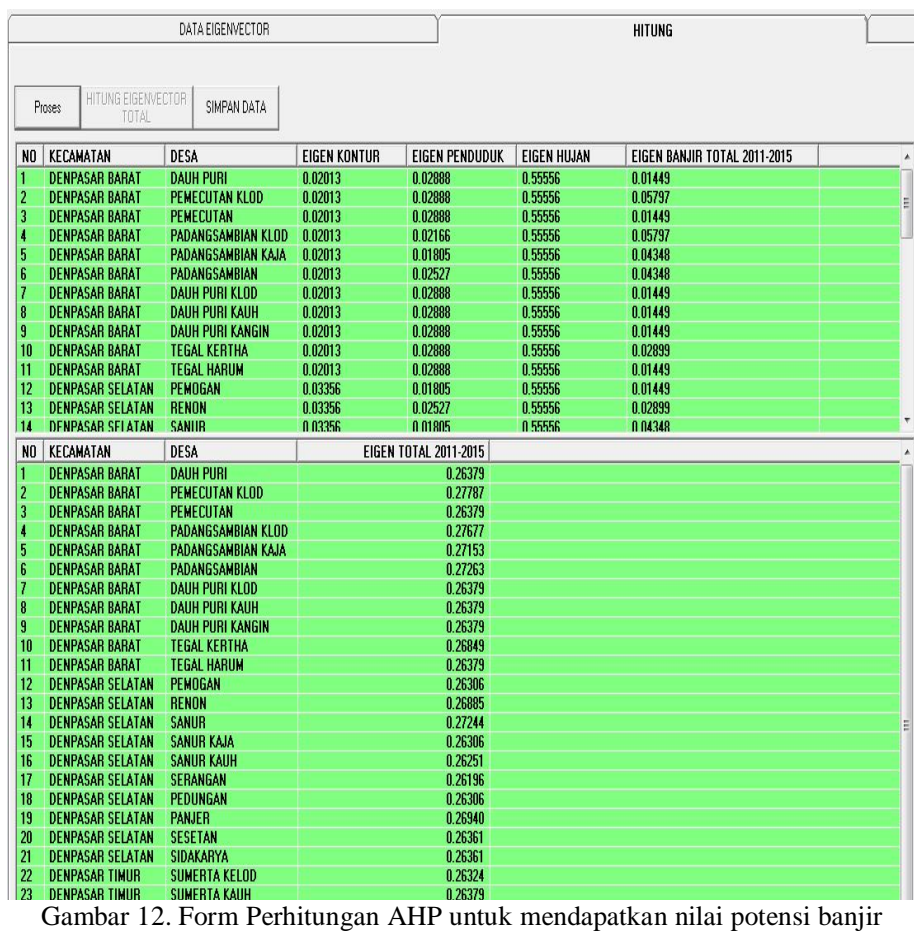

Dari perhitungan sistem diperoleh nilai perbandingan potensi banjir dengan kejadian banjir 2011 sampai dengan 2015 dapat dilihat pada tabel 12 .

TABEL XII

NILAI POTENSI BANJIR RENDAH TAHUN 2011 S.D 2015

\begin{tabular}{|c|c|c|c|c|c|c|c|}
\hline NO & KECAMATAN & DESA & $\begin{array}{l}\text { BANJIR } \\
2011- \\
2015\end{array}$ & $\begin{array}{c}\text { KRITE } \\
\text { RIA }\end{array}$ & $\begin{array}{l}\text { EIGEN } \\
\text { BANJIR }\end{array}$ & LEVEL & $\begin{array}{l}\text { PERBAN } \\
\text { DINGAN }\end{array}$ \\
\hline 1 & DENPASAR BARAT & DAUH PURI & 0 & RENDAH & 0,26379 & RENDAH & SESUAI \\
\hline 2 & DENPASAR BARAT & PEMECUTAN & 0 & RENDAH & 0,26379 & RENDAH & SESUAI \\
\hline 3 & DENPASAR BARAT & DAUH PURI KLOD & 0 & RENDAH & 0,26379 & RENDAH & SESUAI \\
\hline 4 & DENPASAR BARAT & DAUH PURI KAUH & 0 & RENDAH & 0,26379 & RENDAH & SESUAI \\
\hline 5 & DENPASAR BARAT & DAUH PURI KANGIN & 0 & RENDAH & 0,26379 & RENDAH & SESUAI \\
\hline 6 & DENPASAR BARAT & TEGAL HARUM & 0 & RENDAH & 0,26379 & RENDAH & SESUAI \\
\hline 7 & DENPASAR SELATAN & PEMOGAN & 0 & RENDAH & 0,26306 & RENDAH & SESUAI \\
\hline 8 & DENPASAR SELATAN & SANUR KAJA & 0 & RENDAH & 0,26306 & RENDAH & SESUAI \\
\hline 9 & DENPASAR SELATAN & SANUR KAUH & 0 & RENDAH & 0,26251 & RENDAH & SESUAI \\
\hline 10 & DENPASAR SELATAN & SERANGAN & 0 & RENDAH & 0,26196 & RENDAH & SESUAI \\
\hline 11 & DENPASAR SELATAN & PEDUNGAN & 0 & RENDAH & 0,26306 & RENDAH & SESUAI \\
\hline 12 & DENPASAR SELATAN & SESETAN & 0 & RENDAH & 0,26361 & RENDAH & SESUAI \\
\hline 13 & DENPASAR SELATAN & SIDAKARYA & 0 & RENDAH & 0,26361 & RENDAH & SESUAI \\
\hline 14 & DENPASAR TIMUR & SUMERTA KELOD & 0 & RENDAH & 0,26324 & RENDAH & SESUAI \\
\hline 15 & DENPASAR TIMUR & SUMERTA KAUH & 0 & RENDAH & 0,26379 & RENDAH & SESUAI \\
\hline 16 & DENPASAR TIMUR & SUMERTA & 0 & RENDAH & 0,26379 & RENDAH & SESUAI \\
\hline 17 & DENPASAR TIMUR & SUMERTA KAJA & 0 & RENDAH & 0,26379 & RENDAH & SESUAI \\
\hline 18 & DENPASAR TIMUR & DANGIN PURI KLOD & 0 & RENDAH & 0,26214 & RENDAH & SESUAI \\
\hline 19 & DENPASAR TIMUR & KESIMAN & 0 & RENDAH & 0,26269 & RENDAH & SESUAI \\
\hline 20 & DENPASAR TIMUR & $\begin{array}{l}\text { KESIMAN } \\
\text { KERTALANGU }\end{array}$ & 0 & RENDAH & 0,26214 & RENDAH & SESUAI \\
\hline 21 & DENPASAR TIMUR & KESIMAN PET LAN & 0 & RENDAH & 0,26214 & RENDAH & SESUAI \\
\hline 22 & DENPASAR UTARA & UBUNG & 0 & RENDAH & 0,26379 & RENDAH & SESUAI \\
\hline 23 & DENPASAR UTARA & DANGIN PURI KAJA & 0 & RENDAH & 0,26379 & RENDAH & SESUAI \\
\hline 24 & DENPASAR UTARA & DANGIN PURI KANGIN & 0 & RENDAH & 0,26379 & RENDAH & SESUAI \\
\hline 25 & DENPASAR UTARA & DANGIN PURI KAUH & 0 & RENDAH & 0,26379 & RENDAH & SESUAI \\
\hline 26 & DENPASAR UTARA & PEMECUTAN KAJA & 0 & RENDAH & 0,26324 & RENDAH & SESUAI \\
\hline 27 & DENPASAR UTARA & DAUH PURI KAJA & 0 & RENDAH & 0,26379 & RENDAH & SESUAI \\
\hline
\end{tabular}

Untuk potensi banjir rendah dari perhitungan AHP didapat daerah potensi banjir rendah sebanyak 27 desa, jika dibandingkan dengan kejadian banjir keseluruhan dari tahun 2011 sampai dengan tahun 2015 sesuai 100\% karena nihil kejadian banjir. Perbandingan nilai potensi banjir sedang bisa dilihat pada tabel 13 .

TABEL XIII.

NIL AI POTENSI B ANJIR SEDANG TAHUN 2011 S.D 2015

\begin{tabular}{|c|l|l|r|r|r|l|l|}
\hline NO & KECAMATAN & \multicolumn{1}{|c|}{ DESA } & $\begin{array}{c}\text { BANJIR } \\
2011- \\
2015\end{array}$ & $\begin{array}{c}\text { KRITE } \\
\text { RIA }\end{array}$ & $\begin{array}{c}\text { EIGEN } \\
\text { BANJIR }\end{array}$ & LEVEL & $\begin{array}{l}\text { PERBAN } \\
\text { DINGAN }\end{array}$ \\
\hline 1 & DENPASAR BARAT & PADANGSAMBIAN KAJA & 2 & SEDANG & 0,27153 & SEDANG & SESUAI \\
\hline 2 & DENPASAR BARAT & TEGAL KERTHA & 1 & RENDAH & 0,26849 & SEDANG & TIDAK \\
\hline 3 & DENPASAR SELATAN & RENON & 1 & RENDAH & 0,26885 & SEDANG & TIDAK \\
\hline 4 & DENPASAR SELATAN & PANJER & 1 & RENDAH & 0,2694 & SEDANG & TIDAK \\
\hline 5 & DENPASAR TIMUR & PENATIH DANGIN PURI & 1 & RENDAH & 0,26629 & SEDANG & TIDAK \\
\hline 6 & DENPASAR TIMUR & PENATIH & 1 & RENDAH & 0,26684 & SEDANG & TIDAK \\
\hline 7 & DENPASAR TIMUR & DANGIN PURI & 1 & RENDAH & 0,26849 & SEDANG & TIDAK \\
\hline 8 & DENPASAR UTARA & PEGUYANGAN & 2 & SEDANG & 0,27098 & SEDANG & SESUAI \\
\hline 9 & DENPASAR UTARA & TONJA & 1 & RENDAH & 0,26849 & SEDANG & TIDAK \\
\hline 10 & DENPASAR UTARA & PEGUYANGAN KANGIN & 2 & SEDANG & 0,27098 & SEDANG & SESUAI \\
\hline 11 & DENPASAR UTARA & PEGUYANGAN KAJA & 2 & SEDANG & 0,27043 & SEDANG & SESUAI \\
\hline 12 & DENPASAR UTARA & UBUNG KAJA & 1 & RENDAH & 0,26739 & SEDANG & TIDAK \\
\hline
\end{tabular}

Untuk potensi banjir sedang dari perhitungan AHP didapat daerah potensi banjir sedang sebanyak 12 desa, jika dibandingkan dengan kejadian banjir keseluruhan dari tahun 2011 sampai dengan tahun 2015 didapat 4 desa dengan potensi tinggi dengan persentase kecocokan sebesar 33,33\% dari 12 data. Selanjutnya untuk perbandingan nilai potensi banjir tinggi bisa dilihat pada tabel 14 .

TABEL XIV.

NILAI POTENSI BANJIR TINGGI TAHUN 2011 S.D 2015

\begin{tabular}{|l|l|l|l|l|l|l|l|}
\hline NO & KECAMATAN & DESA & $\begin{array}{c}\text { BANJIR } \\
2011- \\
2015\end{array}$ & $\begin{array}{c}\text { KRITE } \\
\text { RIA }\end{array}$ & $\begin{array}{c}\text { EIGEN } \\
\text { BANJIR }\end{array}$ & LEVEL & $\begin{array}{l}\text { PERBAN } \\
\text { DINGAN }\end{array}$ \\
\hline 1 & DENPASAR BARAT & PEMECUTAN KLOD & 4 & TINGGI & 0,27787 & TINGGI & SESUAI \\
\hline 2 & DENPASAR BARAT & $\begin{array}{l}\text { PADANGSAMBIAN } \\
\text { KLOD }\end{array}$ & 7 & TINGGI & 0,27677 & TINGGI & SESUAI \\
\hline 3 & DENPASAR BARAT & PADANGSAMBIAN & 3 & TINGGI & 0,27263 & TINGGI & SESUAI \\
\hline 4 & DENPASAR SELATAN & SANUR & 2 & SEDANG & 0,27244 & TINGGI & TIDAK \\
\hline
\end{tabular}

Untuk potensi banjir tinggi dari perhitungan AHP didapat daerah potensi banjir tinggi sebanyak 4 desa, namun jika dibandingkan dengan kejadian banjir keseluruhan tahun 2011 sampai dengan 2015 didapat 3 desa dengan potensi tinggi dengan persentase kecocokan sebesar $75 \%$ dari 4 data. Total keseluruhan perbandingan nilai potensi banjir dengan kejadian banjir sebanyak 34 desa dengan presentase kecocokan sebesar $79 \%$ dari 43 desa. Eigenvector tertinggi diperoleh desa Pemecutan Klod dengan nilai 0,27787, untuk nilai potensi terendah diperoleh desa Serangan dengan nilai 0,26196. Untuk level potensi banjir di klasifikasi menjadi 3 (tiga) tingkatan yaitu level 1 dengan potensi rendah berwarna hijau, level 2 dengan potensi sedang berwarna kuning dan level 3 dengan potensi tinggi berwarna merah. Berikut banyaknya potensi banjir bisa dilihat pada tabel 15 dibawah ini.

TABEL XV.

BANYAKNYA POTENSI BANJIR

\begin{tabular}{|c|l|r|}
\hline NO & POTENSI BANJIR & BANYAK \\
\hline 1 & TINGGI & 4 \\
\hline 2 & SEDANG & 12 \\
\hline 3 & RENDAH & 27 \\
\hline
\end{tabular}


Berikut persentase banyaknya potensi banjir di kota Denpasar dari perhitungan AHP dapat dilihat pada gambar 13.

\section{PERSENTASE POTENSI BANJIR DI KOTA DENPASAR}

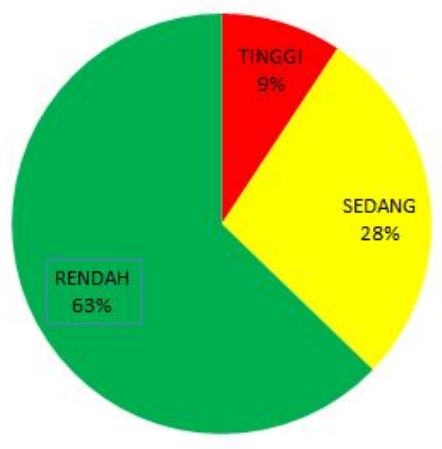

Gambar 13.Persentase potensi banjir dari perhitungan AHP

Setelah mendapatkan nilai eigenvector tersebut dilakukan overlay[18][19[20] nilai ke peta wilayah Denpasar menggunakan Mapinfo dengan menggunakan 3 kemungkinan intensitas curah hujan yaitu : ringan, sedang dan lebat. Asumsi data cuaca dari BMKG dengan intensitas lebat, berikut tampilan hasil peta potensi banjir di wilayah Kota Denpasar dapat diihat pada Gambar 14.

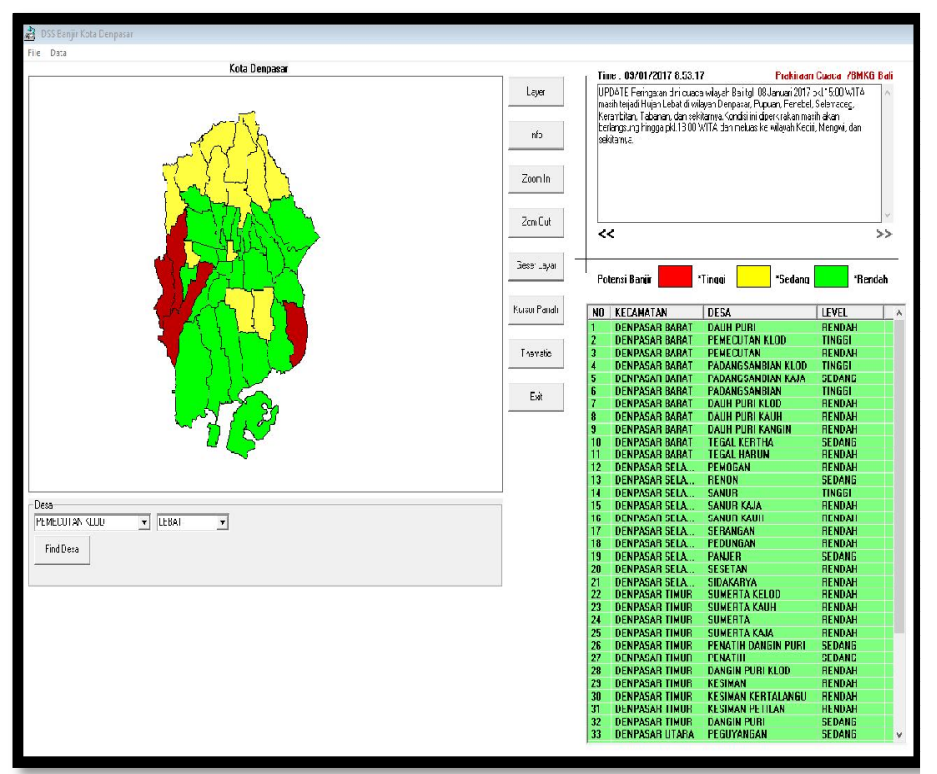

Gambar 14. Form Tampilan Peta Potensi Banjir

Gambar warna peta menunjukkan level tingginya potensi banjir diwilayah Denpasar dengan keterangan warna : merah berpotensi banjir tinggi, kuning berpotensi banjir sedang dan hijau berpotensi banjir rendah. Sebanyak 4 desa di Kota Denpasar dengan warna merah berpotensi banjir tinggi, untuk warna kuning potensi banjir sedang sebanyak 12, sisanya sebanyak 27 Desa berwarnah hijau dengan potensi banjir rendah di Kota Denpasar. Dengan menyajikan data tentang

Junivan : Analisis Potensi Banjir... potensi banjir tersebut akan membantu dalam pengambilan keputusan untuk bertindak dalam masa sebelum bencana, antara lain terkait: kajian lokasi rawan bencana, manajemen bencana, mitigasi berbagai resiko bencana, evakuasi dan penyelamatan.

\section{KeSIMPULAN}

Berdasarkan hasil perhitungan yang telah dilakukan, dapat ditarik kesimpulan sebagai berikut :

1. Untuk uji konsistensi matriks perbandingan berpasangan pada perhitungan potensi banjir di Kota Denpasar, didapat nilai CR sebesar 0,052. Nilai tersebut kurang dari 0,1 sehingga matrik perbandingan berpasangan tesebut konsisten.

2. Penggunaan metode AHP dengan menggunakan 4 (empat) parameter yaitu : ketinggian kontur, cuaca, kepadatan penduduk dan data kejadian bencana dapat menghasilkan rekomendasi potensi banjir di wilayah Kota Denpasar dengan potensi banjir tinggi sebanyak 4 desa, potensi banjir sedang sebanyak 12 desa dan sisanya sebanyak 27 Desa dengan potensi banjir rendah.

3. Setelah dilakukan perbandingan dengan kejadian banjir keseluruhan tahun 2011 sampai dengan 2015 didapat perbandingan nilai potensi banjir sebanyak 34 desa dengan presentase kecocokan sebesar 79\% dari 43 desa di Kota Denpasar.

\section{REFERENSI}

[1] Eko Budi Santoso "Manajemen Risiko Bencana Banjir Kali Lamong Pada Kawasan Peri-Urban Surabaya-Gresik Melalui Pendekatan Kelembagaan” Jurnal Penataan Ruang, Volume 8, Nomor 2, 2013

[2] Jaswadi , R. Rijanta dan Pramono Hadi "Tingkat Kerentanan Dan Kapasitas Masyarakat Dalam Menghadapi Risiko Banjir Di Kecamatan Pasarkliwon Kota Surakarta”. MGI Vol. 26, No. 1, Maret 2012

[3] Peraturan Kepala Badan Nasional Penanggulangan Bencana Nomor 02 Tahun 2012 Tentang Pedoman Umum Pengkajian Risiko Bencana.

[4] Nurul Azizah, Drs. Djalal Er Riyanto, MIKomp, Satriyo Adhy, S.Si, MT "Sistem Pendukung Keputusan Pemberian Bantuan Logistik Bencana Banjir di Jawa Tengah Berdasarkan Proses Hierarki Analitik". Journal of Informatics and Technology, Vol 2, No 3, Tahun 2013 Universitas Diponegoro.

[5] Generino P. Siddayao, Sony E. Valdez, and Proceso L. Fernandez, Oktober 2014,"Analytic Hierarchy Process (AHP) in Spatial Modeling for Floodplain Risk Assessment”. International Journal of Machine Learning and Computing, Vol. 4, No. 5.

[6] Abd Nasir Matori, Dano Umar Lawal, Khamaruzaman Wan Yusof, Mustafa Ahmad Hashim, Abdul-Lateef Balogun "Spatial Analytic Hierarchy Process Model for Flood Forecasting: An Integrated Approach". Earth and Environmental Science 20 (2014).

[7] Muhamad Sholahuddin DS "SIG Untuk Memetakan Daerah Banjir Dengan Metode Skoring Dan Pembobotan Studi Kasus Kabupaten Jepara". Sistem Informasi, Fasilkom, Udinus.

[8] Muhammad Pramulya, Komarsa Gandasasmita dan Boedi Tjahjono "Kajian Geomorfologi, Bahaya Dan Risiko Banjir, Serta Aplikasinya Untuk Evaluasi Tata Ruang Kota Sintan”. Oktober 2011.

[9] Indrianawati, D. Muhally Hakim dan Albertus Deliar "Penyusunan Basis Data untuk Identifikasi Daerah Rawan Banjir Dikaitkan dengan Infrastruktur Data Spasial”.Itenas No.1 Vol. XVII Januari 2013.

p-ISSN:1693 - 2951; e-ISSN: 2503-2372

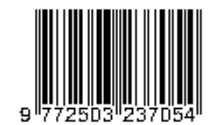


[10] Paimin, Sukresno dan Irfan Budi Pramono 2009 'Teknik Mitigasi Banjir dan Tanah Longsor".

[11] Kadek Sumaja, Komang Ngurah arbawa, Decky Irmawan "Penentuan Produk Radar Cuaca Paling Tepat Untuk Membuat Peringatan Dini Cuaca Ekstrim Dengan Menggunakan Metode Analytic Hierarchy Process (AHP) ”. Buletin Fisika Vol.16 No.1 Februari 2015.

[12] Probo Kusumo, Evi Nursari "Zonasi Tingkat Kerawanan Banjir Dengan Sistem Informasi Geografis Pada Das Cidurian Kab.Serang, Banten”. Jurnal String Vol. 1 No. 1 Tahun 2016

[13] Arna Fariza, S.Kom., M.Kom, Wiratmoko Yuwono, SST., MT, Jauari Akhmad Nur Hasim, SST "Sistem Tanggap Darurat Untuk Manajemen Bencana Menggunakan Software Oriented Arsitektur". Prosiding Conference on Smart-Green Technology in Electrical and Information Systems Bali, 14-15 November 2013.

[14] Dwi Ayu Wira Savitri, D. M. Priyantha Wedagama, dan I G. Putu Suparsa 2015. “Analisis Penentuan Prioritas Penanganan Jalan Di Kota Denpasar Berdasarkan Metode Analytic Hierarchy Process (AHP) Dengan Kombinasi Metode Fuzzy Analytic Hierarchy Process (FAHP) Dan Topsis". Jurnal Spektran Vol.3, No.1, Januari 2015.

[15] Hendi Hamdani, Sulwan Permana, Adi Susetyaningsih 2014 "Analisa Daerah Rawan Banjir Menggunakan aplikasi sistem informasi geografis (studi kasus pulau bangka)". ISSN: 2302-7312 Vol. 12 No. 12014.

[16] Ayu Permata Shabrina Putri, Muhamad Shantya Utama, Rizki Nasibah Rachmania, Rayinda Pramuditya Soesanto "Perancangan Sistem Pendukung Keputusan dan Sistem Informasi Geografis Pemberian Bantuan Korban Banjir di Kabupaten Bandung Selatan”. Seminar Nasional IENACO-2014

[17] Dano Umar Lawa, Abdul-Nasir Matori, Ahmad Mustafa Hashim, Khamaruzaman Wan Yusof and Imtiaz Ahmed Chandio "Detecting Flood Susceptible Areas Using GIS-based Analytic Hierarchy Process". 2012 International Conference on Future Environment and Energy.

[18] Th. Dwiati Wismarini dan Muji Sukur "Penentuan Tingkat Kerentanan Banjir Secara Geospasial”. Jurnal Teknologi Informasi Dinamik Volume 20, No.1, Januari 2015.

[19] Nyoman Winda Novitasari, Arief Laila Nugraha, Andri Suprayogi Pemetaan Multi Hazards "Berbasis Sistem Informasi Geografis Di Kabupaten Demak Jawa Tengah”. Jurnal Geodesi Undip Oktober 2015.

[20] Yashon O. Ouma, Ryutaro Tateishi "Urban Flood Vulnerability and Risk Mapping Using Integrated Multi-Parametric AHP and GIS: Methodological Overview and Case Study Assessment”. 2014. 